\title{
Effect of Earnings Per Shares on Capital Structure Choice of Listed Non-Financial Firms in Nigeria
}

\author{
Olanrewaju Isola Fatoki \\ Tobias Olweny, PhD
}

Department of Economics, Accounting and Finance

Jomo Kenyatta University of Agriculture and Technology, Nairobi, Kenya

Doi: 10.19044/esj.2017.v13n34p230 URL:http://dx.doi.org/10.19044/esj.2017.v13n34p230

\begin{abstract}
The main objective of this paper is to examine the effect of financial performance on capital structure of listed non-financial firms in Nigeria. This was guided by assessing the earnings per share on capital structure choice. The causal research design was adopted while a total of 87 samples was included in the study. The estimated results are statistically significant at all levels of Capital Structure. Based on the significance of these results it was concluded that both the efficiency risk and franchise value hypotheses of the reverse causality hypothesis are observable in the capital structure choice of the firms.
\end{abstract}

Keywords : Frim performance, Capital Structure, Reverse Causality Hypothesis, Earnings per Shares

\section{Introduction}

Financial performance can be described as the extent to which financial goal of a firm is being or has been accomplished. It is the process of measuring the results of an organisation's policies and operations in monetary terms. It measures the overall financial health of a firm over a given period of time. According to Chakravarthy, (1986) it is a way to satisfy investors and can be represented by profitability, growth and market value (Cho \& Pucik, 2005; Venkatraman \& Ramanujam, 1986). These three aspects complement each other. Profitability measures a firm's past ability to generate returns (Glick et al., 2005). Growth demonstrates a firm's past ability to increase its size (Whetten, 1987). Increasing size, even at the same profitability level, will increase its absolute profit and cash generation. Larger size also can bring economies of scale and market power, leading to enhanced future profitability. 
Theoretically, the importance of financial performance derives from the fact that it is strongly related to the ability of firms to fulfill the needs of various stakeholders while the research on the relationship between financial performance and capital structure is gathering momentum Berger \& Bonaccorsi di Patti (2002, 2006); Margaritis and Psillaki (2010), Otieno and Nwangwe (2015), Yinusa, Somoye, Alimi and Ilo (2016), whereas, the relationship between capital structure and financial performance has been a topical issue and one of the most interesting issues in the corporate finance literature since late 1950s studies of Lintner (1956) and Modigliani and Miller (1958). However, Modigliani and Miller (1958, 1963) seminar work on the irrelevance of capital structure on firm value and later supported by Miller (1977) indeed spark off the debate on capital structure (Muritala, 2014; Ogebe, Ogebe \& Alewi, 2013). This has led to the emergency and development of new theories on the issue of capital structure and firm performance. Additional capital structure theories, such as the static tradeoff theory and the pecking order theory have emerged over the years.

Previous researches on the effect of firm's financial performance on capital structure choice is explained by the reverse causality hypothesis. This hypothesis involves two theories, the efficiency-risk hypothesis and the franchise value hypothesis. A study by Berger and Bonaccorsi di Patti (2006) suggests that efficient firms will have better performance and generate higher returns. Therefore, they may have a better position to replace equity shares with debt in their capital structure. Based on the efficiency-risk hypothesis, to lessen the possibility of bankruptcy and financial distress, firms with better performance will choose a higher leverage ratio. In contrast, the franchise-value hypothesis suggests that firms with better performance will choose a lower leverage ratio to protect their future income. This hypothesis is supported by Berger and Bonaccorsi di Patti (2006) and Demzetz (1973), who found that efficient firms increase their efficiency by lowering the ratio of debt to equity. In addition, lower leverage is needed to sustain the economic rents or franchise value to avoid liquidation. A study by Margaritis and Psillaki (2010) on capital structure, equity ownership and firm performance of a sample of French firms concluded that leverage has a positive impact on firm efficiency, and vice versa.

Studies on the effect of Capital structure on financial performance is not a new phenomenon to Nigeria corporate finance researcher, many researchers have tried to deal with the signs of their relationship, the causal effect while others have examined determinants and tested the existing theories (Abata Migiro, 2016; Akintoye, 2008, 2009; Muritala, 2014; Oladeji, Ikpefan \& Olokoyo, 2015; Onaolapo \& Kajola, 2010). Regardless of the context their findings have been different, mix and inconclusive. The existing literature attributed the cause to the differences in methodological 
approach, choice of variables employed in analysis, duration of the study and the choice of data applied. Another major defect is that virtually all these studies were carried out using a unidirectional approach that only capital structure choice influences the financial performance of a firm without any recourse to assessing the possibility of a reverse causal relationship between performance and capital structure (Yinusa, et al., 2016). Therefore, the aim of this paper is to assess the effect of earnings per shares as a proxy of financial performance on capital structure from the postulation of the reverse causality hypothesis.

\section{Literature Review}

Capital structure refers to the sources of financing, particularly the proportions of debt and equity that a business firm employs to fund its assets, operations and future growth (Jensen \& Meckling, 1979). It is the proportion of financial resources attributed to the firm through different sources, which may include internal and external financers (Abor, 2008). It includes, publicly issued securities, private placements trade debt, bank debt, leasing contracts, pension liabilities, tax liabilities, unpaid compensation to employees and management, performance guarantees, contingent liabilities and other product warrantees (Mireku, Mensa \& Ogoe, 2014).

Since the seminar work of Modgilliani and Miller $(1958,1963)$ on the relevance and irrelevance of capital structure, researchers in corporate financial theory have always been interested in the causal effect of capital structure on financial performance and value of the firm. The classical thinking from the theories propounded since then was premised on a unidirectional causal relationship that capital structure choice determines or affect performance thereby impact on the value of the firm (Kraus \& Litzenberger, 1973; Meckling \& Jensen, 1976; Myer \& Majluf,1984). As a departure from the classical thinking Berger and Bonaccorsi di Patti, (2002), suggested the possibility of a reverse causal relationship as reflected in the reverse causality hypothesis. For instant, debt holders like any other investors always get attracted to profitable and financially sound firms. The theory predicts performance as a factor in explaining the use of debt, which indicates that productive and money-making firms will use more debt (Margaritis \& Psillaki, 2010). The reverse of this proposition is that efficient firms may use less debt to minimize their exposure to financial risk ( $\mathrm{He} \&$ Matvos, 2012). That is, the more profitable and liquid the firm is, the lower the leverage usage (Berger \& Bonaccorsi di Patti 2006; Cheng \& Tzeng, 2011; Margaritis \& Psillak, 2007).

Milad et.al (2013) describes earnings per share (EPS), as one of the most important financial statistics that is noteworthy for investors and financial analysts is which shows earnings that the company has achieved in 
a fiscal period for an ordinary share and often is used to evaluate the profitability and risk associated with earning and judgments about stock prices. EPS can be defined as the ratio of net income to number of equities in a firm (Goya, 2013; Mujahid \& Akhtar, 2014; Savathaasan \& Rathika, 2013) and has been consistently applied as a proxy of performance in various studies, for instant, Mujahid and Akhtar (2014) used the overall textile sector EPS along other ratios as accounting measures to evaluate the impact of capital structure on the financial performance of firms and shareholders' wealth in Pakistan. They conducted regression analysis on a sample of 155 textile firms for the years 2006 to 2011. Their results show that capital structure positively impacts firm financial performance and shareholder wealth.

Mahfuzah and Yadav (2012) investigated the relationship between capital structure and firm performance. They used panel data procedure for a sample of 237 Malaysian listed companies on the Bursa Malaysia Stock exchange during 1995-2011. Four performance measures (including return on equity, return on asset, Tobin's Q and earning per share) were used as dependent variable. The five capital structure measures (including long term debt, short term debt, total debt ratios and growth) were used as independent variables while size was included as a control variable. The results indicated that a firm's performance has a negative relationship with short term debt (STD), long term debt (LTD), total debt (TD). Moreover, they found positive relationships between the growth and performance for all the studied sectors. Tobin's Q reports demonstrated a significantly positive relationship between short term debt (STD) and long-term debt (LTD). It was also concluded that total debt (TD) has a significant negative relationship with the performance of the firm.

Abdulkadir and Sayilir (2015) while examining the relationship between capital structure and firm performance in Borsa Istanbul investigated 130 manufacturing listed firms for the period between 20082013. Using panel data analysis, short term debt to total asset (STDTA) and long-term debt to total asset (LTDTA) are proxies of financial leverage (independent variables) while Return on equity (ROE), return on asset (ROA), earnings per share (EPS) and Tobin's Q ratio were used as proxies of firm performance (dependent variables). Sales growth rate and firm size were used as control variables in the study. Their findings reveal that STDA has a significant negative relationship with ROA, EPS and Tobin's Q ratio. Besides, they find that LTDTA has a significant negative relationship with ROE, EPS and Tobin's Q ratio, while it is positively and significantly correlated with ROA

Sivathaasan and Rathika, (2013) studied the impact of capital structure on earnings per share (EPS) in selected financial institutions listed 
on Colombo Stock Exchange in Sri Lanka during 2006 to 2010. The study employs the distinctive methodologies of correlation and regression model to test the operational hypotheses. The results revealed that Equity and debt ratio have a negative association with EPS, whereas leverage ratio has a positive association according to correlation analysis $(\mathrm{r}=-.244,-.326$ and .389 respectively). In addition, capital structure ratios have an impact which is approximately $\left(\mathrm{R}^{2}\right) 22.6 \%$ on EPS at 0.05 significant levels.

Another effort by Kalpana (2014) to study the impact of leverage on profitability i.e. Earnings per share of selected steel companies traded in BSE shows that that there is a negative correlation between degree of operating leverage and Earning per share, degree of financial leverage and Earning per share, and degree of combined leverage and Earning per share. It is concluded that the use of debt and fixed cost expenses would reduce the profitability of the firms

Anafo, Amponteng and Yin (2015) in determining the impact of capital structure or leverage on profitability employed data collected from 17 listed banks on Ghana stock exchange from 2007 to 2013 using descriptive statistics and multiple regression models. Their result revealed that financial leverage measured by short term debt to total assets (STDTA) had significant positive relationship with profitability measured by return on assets (ROA), return on equity (ROE) and earnings per share (EPS). Long Term Debt to Total Asset (LTDTA) also had a significant positive relationship with ROA and ROE but however, had a negative and insignificant relationship with EPS. Asset growth rate had a negative and insignificant relationship with profitability measured by ROA, ROE and EPS. Firm size also showed positive and significant relation with all the profitability measures such as ROA, ROE and EPS.

\section{Research Methodology}

This section introduces the econometric estimations model used in this study. The data are collected for period of 15 years (from 1999 to 2015) for 87 non-financial firms listed on the Nigeria Stock Exchange. Financial performance was proxies by Earnings per share while the capital structure variables used were total debt to total assets ratio, total debt to total equity ratio and long-term debt to total assets ratio. The effect of financial performance on capital structure for the sampled firms was estimated using the General Method of Moments (GMM) because it allows lagged values of the independent variables to be included as explanatory variable. While some tests carried out in this instance employed the OLS model, however, based on the theoretical postulation of the reverse causality hypothesis, the basic problem of using OLS is that the lagged dependent variable is correlated with the error term as the dependent variable is a function of error term and it 
immediately follows that lagged dependent variable is also a function of error term. The fixed effect (FEM) and random effect (REM) estimators are also biased and inconsistent unless the number of time periods is large (Baltagi, 2002). Therefore, this study exploits the GMM technique of Arellano and Bond (1991), which suggests to first difference the model and to use lags of the dependent and explanatory variables as instruments for the lagged dependent variable as a regressor.

follows:

The general empirical model used in this study was defined as

Capital Structure $=f$ (Financial Performance) 3.1

This Equation was transformed to a GMM model as shown in equation 3.2

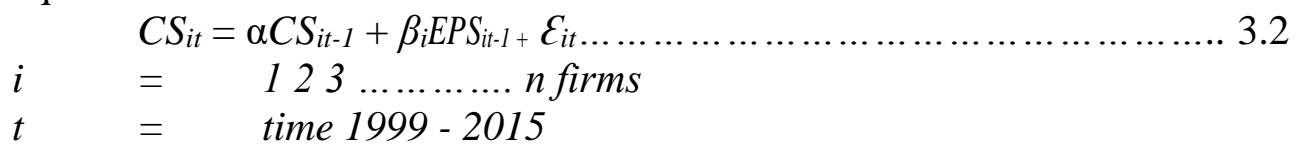

Where: $C S$ is Capital structure as measured by Total debt ratio (TDR), Debt to equity ratio (DER) and Long-term debt ratio (LTD) while EPS is Earnings per Share. $\alpha$ is the constant and $\beta_{i}$ is the parameter estimates of the explanatory variables while $\varepsilon_{i t}$ is the error term.

\section{Results and Discussion}

The formulated null hypothesis was that Earnings per Share (performance) has no significant effect on Capital structure as measured by total debt ratio (TDR), debt to equity ratio (DER) and long-term debt ratio (LTD). To validate or otherwise the effect of financial performance on capital structure choice, a thorough analysis conducted using GMM was presented in Table 1.

Table 1: GMM estimated results of effect of Earnings Per Share (performance) on Capital Structure Dependent Variables TDR, DER and LTD

\begin{tabular}{cccc}
\hline Explanatory variables & Model1 & Model2 & Model3 \\
\hline CS $_{\text {it-1 }}$ & 0.892248 & 0.439197 & 0.801192 \\
& $(0.000)$ & $(0.000)$ & $(0.000)$ \\
EPS $_{\text {it-1 }}$ & $-5.50 \mathrm{E}-05$ & 0.003982 & 0.000225 \\
& $(0.000)^{* *}$ & $(0.000)^{* *}$ & $(0.000)^{* *}$ \\
\hline Observation & 1305 & 1305 & 1305 \\
Companies & 87 & 87 & 87 \\
Periods included & 15 & 15 & 15 \\
Instrument rank & 40 & 57 & 40 \\
Arellano and Bond AR (2) & 0.261 & 0.579 & 0.228 \\
Hansen Test p value & 0.388 & 0.314 & 0.579 \\
\hline
\end{tabular}

Models $1,2 \& 3$ Total debt to Total assets, Total debt to Total Equity \& Long-term debt to Total assets leverage models

* Significant at $1 \%, * *$ Significant at $5 \%$, and *** Significant at $10 \%$ 
The output in Table 1 shows a negative significant relationship between financial performance as measured by Earnings Per shares and Capital Structure (total leverage to total asset). The estimated result of model 1 pulled a coefficient of $-5.50 \mathrm{E}-05$ and corresponding $\mathrm{P}$ value of 0.000 . For the Arellano and Bond (AR2) test of second order autocorrelation, a value of 0.261 which is greater than 0.05 was obtained which suggest the absence of second order autocorrelation, denotating that the model was correctly specified. The Hansen test of instrument validity and first difference condition shows probability value of 0.388 signifying that the instruments used in the estimated model are valid instruments since the probability value of the Hansen test was greater than 0.1. The estimated model maintained the rule of the thumb as regard instruments and groups that is, the number of instrument is expected to be less or equal to the number of groups as shown on the Table 1.

To further validate the effect, of financial performance in the context of EPS on capital structure, as measured by DER. The estimated result of model 2 indicate that a statistically significant positive relationship exists between firm performance (EPS) and capital structure (TDR). The estimated result produced a coefficient of 0.003982 and $\mathrm{P}$ value of 0.000 . The Arellano and Bond tests of autocorrelation show (AR2) value of 0.579 which is greater than 0.05 connotes the absence of second order autocorrelation suggesting that the model is correctly specified. The Hansen test of instrument validity at first difference shows probability value that is not less than 0.1 which stood at 0.314 . This suggests that the instruments used in the estimated models are valid instruments while the instrument ranking further satisfied the rule of the thumb that the number of instrument should be less or equal to the number of groups.

In addition, to strengthen and expand the horizon of the study in determining the effect of financial performance in the context of EPS on capital structure using long term debt to total assets as a measure of leverage, the estimated result of model 3 in Table 1, revealed that a statistically significant positive relationship exists between firm financial performance (EPS) and capital structure (long term leverage). This is confirmed by a coefficient value of 0.00225 and an associated $\mathrm{P}$ value of 0.000 . The Arellano and Bond tests of autocorrelation show (AR2) value of 0.329. Since this autocorrelation value is greater than 0.05 the implication is that the problem of second order autocorrelation do not exist meaning the model was correctly specified. The Hansen test of instrument validity at first differencing produced a probability value of 0.579 which is greater than 0.1 connoting that the instruments used in the estimated models are valid instruments which was further satisfied by rule of the thumb that the number of instrument should be less or equal to the number of groups. 
The consequence of the negative significant relationship found between firm performance (EPS) and capital structure proxied by total debt ratio is that the capital structure choice of firms in Nigeria respond negatively to financial success of the firms in achieving optimal usage of debt in place of equity. That is, the more efficient the management of firms in Nigeria are at increasing the EPS of the firm the more the possibility of the operations being financed by equity capital rather than debt. In line with findings of Margaritis and Psillaki (2007) in the behaviours of firms in New Zealand and and Yinusa, et.al. (2016) among Nigeria firms. This finding is consistent with the theoretical stance of the franchise value hypothesis which postulates that profit is a source of rents, and that firm holds additional equity capital to prevent the loss of these rents in the event of liquidation. However, the positive effect recorded on debt to equity ratio long-term leverage is consistence with the efficiency risk hypothesis as observe in Ghana and Taiwanese banks by Ayuki (2015) and Yeh (2010) respectively. This hypothesis postulates that, more efficient firms choose lower equity ratios than other firms, all else equal, because higher efficiency reduces the expected costs of bankruptcy and financial distress. This infers that the past financial performance of firms in Nigeria is reflected in their choice of capital structure combination. The study therefore rejects the null hypothesis and accepts alternative hypothesis based on the estimated results that there is statistically significant relationship between firm performance as measured by earnings per shares and capital structure as measure by TDR, DER and LTD of firms in the Nigeria Stock Exchange.

Estimation Equation:

$\mathrm{CS}_{\mathrm{it}}=\alpha \mathrm{CS}_{\mathrm{it}-1}+\beta_{1} \mathrm{EPS}_{\mathrm{it}-1}+\varepsilon_{\mathrm{it}}$

Substituted Coefficients:

Model $1 \mathrm{CS}_{1}=0.8924448 \mathrm{CS}_{1 \mathrm{t}-1}-5.50 \mathrm{E}-05 \mathrm{EPS}_{\mathrm{it}-1}$

Model 2CS $2=0.439197 \mathrm{CS}_{2 \mathrm{t}-1}+0.003982 \mathrm{EPS}_{\mathrm{it}-1}$

Model 3CS $3=0.801192 \mathrm{CS}_{3 \mathrm{t}-1}+0.000225 \mathrm{EPS}_{\mathrm{it}-1}$

\section{Summary of Findings}

The key finding in this study has to do with the effect of earnings per share on capital structure. Interestingly this variable according to the estimated result has a negative significant effect on total debt while it has a positive effect on debt equity ratio and long-term leverage. The interpretation of this development is that the more the earning powers of the return on the shares of these companies the more the reluctant effect it will have on the injection of more debt in the capital structure. The reason is not far fetch shareholders and other interested parties in the organization view will be 
different in the sense that it will be seeing as an improvement on the profitability position and injection of more debt will affect their ownership status and return on their investment, in view of this, management may not have option than to look inward. On the other hand, the positive effect its having on debt equity ratio and long-term leverage shows that the companies sampled can only commensurate their financial performance with long-term financial needs which may not likely to be frequent. In addition, this is a strong support for the existence of the efficiency risk and franchise value hypotheses of the reverse causality hypothesis in capital structure choice of companies in the Nigerian stock exchange.

\section{Conclusion}

Supported by the empirical findings of this study as documented, quite a number of logical conclusions were drawn. The researchers concluded that firm's past financial performance has effects on the capital structure choice of non-financial firms on the Nigerian using earnings per shares as proxy of financial performance. In addition, this study conforms with earlier researchers' findings that there exists both efficiency risk and franchise value hypotheses of the reverse causality hypothesis in the choice of their capital structure mix on the platform from which their research was based. From the perspective of this study it was however confirmed that the firms in Nigeria do not only exhibit franchise value hypothesis but also efficiency risk hypothesis as exhibited in the findings.

\section{References:}

1. Abata, M. A, \& Migiro, S. O. (2016). Capital structure and firm performance in Nigerian-listed companies. Journal of Economics and Behavioral Studies 8(3), 54-74.

2. Abdulkadir, A. T. A \& Ozlem, S (2015). Capital Structure and firm performance: An analysis of manufacturing firms in Turkey. Eurasian Journal of Business and Management, 3(4), 13- 22.

3. Ayuki, N. S. (2015). Profit efficiency and capital structure of banks in Ghana: A DEA approach. Unpublished MPhil thesis, Department of Finance, University of Ghana. Legon.

4. Baltagi B. H. (2002) Econometric Analysis of Panel Data, ( $\left.{ }^{\mathrm{rd}} \mathrm{ed}\right)$. John Wiley and Sons.

5. Berger, A. N. \& Bonaccorsi di Patti, E. (2006). Capital structure and firm performance: A new approach to testing agency theory and an application to the banking industry. Journal of Banking \& Finance, 30(4), 1065-1102. 
6. Chakravarthy, B. S. (1986). Measuring strategic performance. Strategic Management Journal, $\quad 7(5), \quad 437-458 . \quad$ doi: 10.1002/smj.4250070505

7. Cho, H., \& Pucik, V. (2005). Relationship between innovativeness, quality, growth, profitability, and market value. Strategic Management Journal, 26(6), 555-575. doi: 10.1002/smj.461.

8. Demsetz, H. (1973). Industry structure, market rivalry and public policy. Journal of Law and Economics, 16(1), 1-9.

9. Fazle, R., Tahir, A., Ahmad, Z. \& Mohammed A. T. (2016). Capital structure and firm efficiency: Case of Pakistan. Indian Journal of Finance, 10(2), 50-66.

10. Glick, W. H., Washburn, N. T., \& Miller, C. C. (2005). The myth of firm performance. Proceedings of the Annual Meeting of American Academy of Management. Honolulu, Hawaii.

11. Goyal, A.M. (2013). Impact of capital structure on performance of listed public-sector banks in India. International Journal of Business and Management Invention, 2(10), 35-43.

12. Gujarati, D. N. (2013). Basic econometrics, (5th ed.). New York: The McGraw-Hill Companies.

13. Jensen, M. C, \& Meckling, W. H. (1976). Theory of the firm: Managerial behaviour, agency costs and capital structure. Journal of Financial Economics, 3(4), 305-360.

14. Margaritis, D., \& Psillaki, M. (2007). Capital structure and firm efficiency. Journal of Business $\quad$ Finance and Accounting, 34(910), 1447-1469.

15. Margaritis, D., \& Psillaki, M. (2010). Capital structure, equity ownership and firm performance. Journal of Banking and Finance, 34(3), 621-632.

16. Milad, E., Abbasali, P., Naser, A. Y. T., Milad, H. \& Ali, A. A. S. (2013). The effects of performance evaluation market ratios on the stock return: Evidence from the Tehran stock exchange. International Research Journal of Applied and Basic Sciences, 4 (3), 696- 703.

17. Miller, M. H. (1977). Debt and taxes. Journal of Finance, 32(2), 261-275.

18. Muritala, T. A. (2012). An empirical analysis of capital structure on firms' performance in Nigeria. International Journal of Advances in Management and Economics, 1(5), 116-124.

19. Ogebe, J. O., Ogebe, P. O. \& Alewi, K. (2013). The Impact of capital structure on firms' performance in Nigeria. MPRA Paper No. 46173. Retrieve March 27, 2017, from http://mpra.ub.unimuenchen.de/46173. 
20. Oladeji, T., Ikpefan, A. O \& Olokoyo, F. O. (2015). An Empirical analysis of capital structure on performance of firms in the petroleum industry in Nigeria. Journal of Accounting and Auditing: Research \& Practice. 2015(2015) Article ID 675930, DOI: 10.5171/2015.675930.

21. Olowe, O., Matthew, O., \& Fasina, F. (2011). Nigerian stock exchange and economic development Knowledge

Management, Information Management, Learning Management, 14. 14-38.

22. Onaolapo, A. A., \& Kajola, S. O. (2010). Capital structure and firm performance: evidence from Nigeria. European Journal of Economics, Finance and Administrative Sciences, 25, 70-82.

23. Onaolapo, A. A., Kajola, S. O \& Nwidobie, M. B. (2015). Determinants of capital structure: A study of Nigerian quoted companies. European Journal of Business and Management 7(23), 170-183.

24. Otieno, O. L. (2015). The Relationship between capital structure, performance and replacement of CEO in firms listed on the Nairobi Securities Exchange. Unpublished Doctor of Commerce Thesis, University of South Africa. Pretoria.

25. Otieno, O. L. \& Ngwenya, S. (2015). Bi-directional relationship between capital structure and financial performance of firms listed on the Nairobi Securities Exchange. Corporate Ownership and Control, 12(4), 103 - 116.

26. Sivathaasan, N. \& Rathika, S. (2013). Capital structure and EPS: a study on selected financial institutions listed on Colombo stock exchange (CSE) in Sri Lanka. European Journal of Business and Management, 5(14), 69-73.

27. Venkatraman, N. \& Ramanujam, V. (1986). Measurement of business performance in strategy research: A comparison of approaches. Academy of Management Review, 1(4), 801-814. doi: $10.2307 / 258398$

28. Yeh, H. H. \& Roca, E. (2010). Macroeconomic conditions and capital structure: Evidence from Taiwan. Griffith Business School, Discussion papers: Finance, (2010-14).

29. Yeh, T. L. (2010). Bank loan loss provision decisions: Empirical analysis of Taiwanese banks. Journal of Financial Services Marketing, 14(4), 278-289.

30. Yeh, T. L. (2011). Capital structure and cost efficiency in the Taiwanese banking industry. The Service Industries Journal, 31(2), 237-249. 
31. Yinusa, O. G. (2015). Dynamic analysis of the impact of capital structure on firm performance. Unpublished PhD Thesis, Faculty of Business and Law, De Montfort University. Leicester, England.

32. Yinusa, O. G., Russell, O., Somoye, C., Alimi, O. Y. \& Ilo, B. M. (2016). Firm performance and capital structure choice of firms: Evidence from Nigeria Journal of Knowledge Globalization, 9(1), 1-16. 